\title{
Komposisi dan Aktivitas Antibakteri Asap Cair Limbah Kulit Batang Mangrove dengan Teknik Pembakaran Non Pirolisis
}

\author{
Gracelia Monica $^{1 *}$, Fransisca Monita Wenisda ${ }^{1}$, Nora Idiawati ${ }^{1}$, Mega Sari \\ Juane Sofiana $^{1}$, Ika Safitri ${ }^{1}$ \\ 1 Program studi Ilmu Kelautan, FMIPA, Universitas Tanjunpura, Pontianak- \\ Indonesia \\ *Correspondence email: Gracelia Monica \\ هraceli.siahaan33a@gmail.com
}

Received:26 September 2019- Accepted: 2 October 2019

Published: 31 October 2019 C Author(s) 2019. This article is open access

\begin{abstract}
Asap cair telah dihasilkan dari limbah kulit batang mangrove dengan menggunakan metode pirolisis. Proses pemurnian asap cair dilakukan menggunakan metode destilasi pada suhu $150^{\circ}$. Asap cair tanpa destilasi menunjukkan aktivitas antibakteri terhadap bakteri E. coli dan S. aureus. Asap cair hasil destilasi tidak menunjukkan aktivitas antibakteri terhadap bakteri E. coli dan S. aureus. Analisis GC-MS menunjukan 12 senyawa kimia aktif dalam asap cair tanpa destilasi dan 7 senyawa kimia aktif dalam asap cair hasil destilasi. Sifat antibakteri asap cair tersebut diharapkan dapat menjadi alternatif pengganti pengawet yang berbahaya bagi pangan.
\end{abstract}

Keywords: Asap Cair, Pirolisis, Antibakteri, Escherichia coli, Staphylococcus aureus

\section{Pendahuluan}

Besarnya Hutan mangrove di Kalimantan Barat memiliki luas total \pm 280.875 ha (DKP Kalbar, 2014). Mangrove dapat dimanfaatkan dalam pembuatan arang. Salah satu industri arang yang terdapat di Kalimantan Barat yaitu berada di Kecamatan Batu Ampar, Kabupaten Kubu Raya. Batang pohon mangrove digunakan sebagai bahan baku produksi pembuatan arang. Produksi arang tersebut menghasikan limbah berupa kulit mangrove. Kelimpahan limbah kulit mangrove di industri tersebut menyebabkan limbah ini dapat mencemari lingkungan perairan. Salah satu alternatif pemanfaatan limbah kulit mangrove yaitu dengan diolah menjadi asap cair. Potensi asap cair sudah banyak diteliti sebagai antibakteri. Asap cair yang diolah dari tandan kosong sawit mengandung senyawa fenol dan asam asetat yang berperan aktif sebagai antibakteri (Lestari et al., 2015). Kondo (2017) menyatakan bahwa asap cair pada konsentrasi $6,25 \%$ dapat menghambat pertumbuhan bakteri Streptococcus sanguis. Zuraida et al., (2009) menemukan asap cair dari tempurung kelapa dapat dijadikan sebagai antibakteri terhadap bakteri Staphylococcus aureus dan Pseudomonas aeruginosa serta dapat memperpanjang umur simpan bakso ikan. 


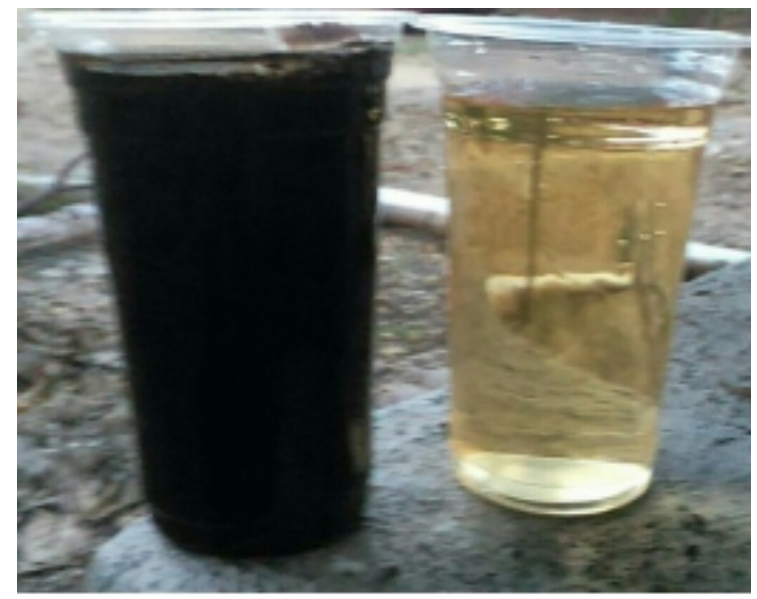

Gambar 1. Asap Cair tanpa destilasi dan Asap Cair Hasil destilasi

Selanjutnya Harini dan Wachid (2014) melakukan penelitian pembuatan asap cair dari tempurung kelapa, tongkol jagung, dan bambu yang dijadikan sebagai antibakteri pada berbagai konsentrasi dan lama penyimpanan pada ikan mujair. Penelitian tersebut menunjukan bahwa asap cair mempunyai kemampuan dalam menghambat bakteri patogen (Eschericia coli, $P$. aeuginosa, Bacillus subtilis, dan S. aureus).

Asap cair di Indonesia pada umumnya telah diteliti. Akan tetapi, masyarakat Indonesia kesulitan dalam memproduksi asap cair. Hal ini disebabkan karena sulitnya dalam memproduksi alat pirolisis. Asap cair sabut kelapa yang dibuat dengan teknik pembakaran memiliki aktivitas antibakteri terhadap bakteri Salmonella choleraesuis, Bacillus subtilus dan Staphylococcus aureus (Fatimah, 2011).

Pemanfaatan limbah kulit mangrove sebagai asap cair diharapkan memiliki kandungan senyawa yang dapat menghambat pertumbuhan bakteri. Pada penelitian ini, uji aktivitas antibakteri asap cair dilakukan menggunakan bakteri E. coli dan S. aureus. Oleh karena itu, penelitian ini perlu dilakukan untuk mengetahui aktivitas antibakteri pada bakteri tersebut serta pemanfaatan limbah kulit mangrove sebagai bahan baku pembuatan asap cair dapat mengurangi pencemaran di perairan Batu Ampar.

\section{Metode}

\subsection{Waktu dan tempat}

Penelitian ini dilakukan selama 5 bulan yang meliputi pengambilan sampel, pembuatan asap cair, uji antibakteri dan analisis senyawa kimia dengan GC-MS. Bahan baku asap cair berupa limbah kulit mangrove diporoleh dari Batu Ampar, Kalimantan Barat dan dianalisis di Laboratorium Kimia dan Biologi Fakultas Matematika dan Ilmu Pengetahuan Alam, Universitas Tanjungpura

\subsection{Proses Pirolisis dan Destilasi}

Pembuatan asap cair limbah kulit batang mangrove dilakukan dengan teknik pirolisis. Rangkaian alat terdiri dari komponen tungku pembakaran yang terbuat dari drum dilengkapi dengan cerobong asap terbuat dari alumunium serta komponen pendingin gelas dengan panjang $1,5 \mathrm{~m} .20 \mathrm{~kg}$ limbah kulit

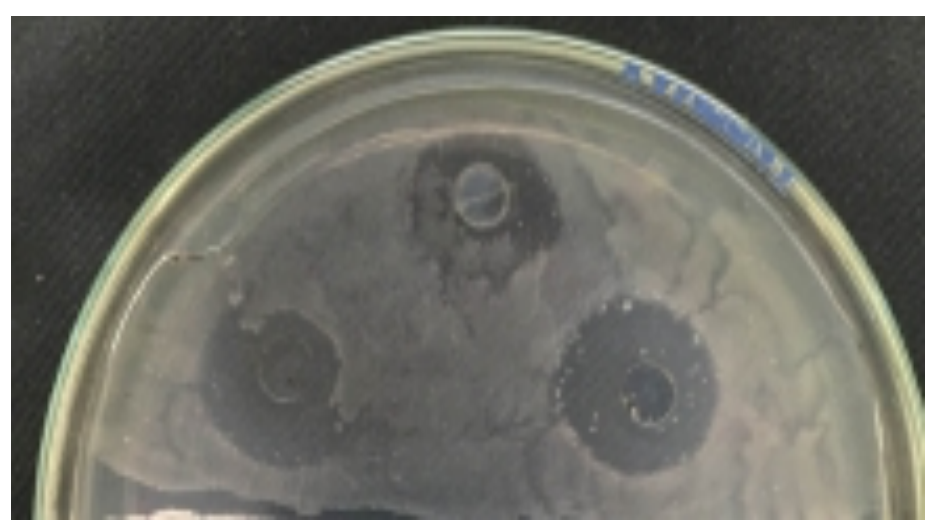

Gambar 2. Hasil Uji Aktivitas Antibakteri 
batang mangrove dibakar. Asap cair hasil pembakaran dikondensasikan pada kondensor kemudian ditampung pada penampung asap. Asap cair dilakukan destilasi pada suhu $150^{\circ} \mathrm{C}$. kecokelatan dan memiliki bau yang khas. Asap cair yang diperoleh selanjutnya diendapkan selama 24 jam untuk memisahkan antara tar dengan asap cair.

Asap cair yang telah diendapkan terbagi

Tabel 1. Penghambatan Pertumbuhan Bakteri E. coli dan S. Aureus menggunakan Asap Cair Limbah Kulit Batang Mangrove

\begin{tabular}{ccc}
\hline \multirow{2}{*}{ Perlakuan } & \multicolumn{2}{c}{$\begin{array}{c}\text { Diameter zona hambat } \\
(\mathbf{m m})\end{array}$} \\
\cline { 2 - 3 } & E.coli & S.aureus \\
\hline A volume $5 \mu \mathrm{L}$ & 0 & 0 \\
A volume $10 \mu \mathrm{L}$ & 0 & 0 \\
A volume $15 \mu \mathrm{L}$ & 0 & 0 \\
A volume $20 \mu \mathrm{L}$ & 0 & 0 \\
B volume $5 \mu \mathrm{L}$ & 8,40 & 10,08 \\
B volume $10 \mu \mathrm{L}$ & 8,65 & 10,45 \\
B volume $15 \mu \mathrm{L}$ & 9,24 & 11,20 \\
B volume $20 \mu \mathrm{L}$ & 10,42 & 12,76 \\
\hline
\end{tabular}

Keterangan : A : asap air limbah kulit batang mangrove hasil destilasi; B : Asap cair limbah kulit batang magrove tanpa destilasi

\subsection{Analisis Data \\ 2.3.1 Uji Antibakteri}

Uji antibakteri dilakukan terhadap bakteri $E$. coli dan S.aureus dilakukan dengan metode cakram kertas. Volume asap cair yang digunakan adalah $5 \mu \mathrm{L} ; 10 \mu \mathrm{L} ; 15 \mu \mathrm{L} ; 20 \mu \mathrm{L}$. Isolat bakteri uji yang ditumbuhkan pada media yang berumur 24 jam, digoreskan ke cawan petri yang sudah ditambahkan asap cair pada cakram kertas. Aktivitas antibakteri masing-masing asap cair ditunjukkan dengan mengukur zona bening yang terbentuk di sekeliling kertas cakram (Fatimah, 2011).

\subsubsection{Analisis GC-MS}

Analisis asap cair dengan menggunakan GC-MS-QP 2010 SHIMADZU dengan kolom low polarity jenis Rtx 5 MS panjang 30 $\mathrm{m}$. Digunakan detektor dengan suhu $250^{\circ} \mathrm{C}$, suhu kolom awal $40^{\circ} \mathrm{C}$ dan suhu akhir $310^{\circ} \mathrm{C}$. Gas pembawa adalah helium dengan laju alir $27,3 \mathrm{~cm} / \mathrm{sec}$ pada tekanan $13,0 \mathrm{kPa}$ dan banyaknya injeksi $1 \mu \mathrm{L}$

\section{Hasil dan Pembahasan}

Proses pirolisis berlangsung \pm 8 jam dan menghasilkan destilat berupa cairan, padatan dan gas (Gambar 1). Asap cair yang dihasilkan berwarna hitam pekat kecoklatan dan berbau menyengat. Asap cair yang diperoleh sama dengan Bridgwater (2004), yang mengatakan asap cair berwarna menjadi dua lapisan. Lapisan dasar yang merupakan tar dan lapisan atas yang merupakan asap cair. Asap cair dipisahkan dari tar dengan cara disaring. Hal ini bertujuan untuk mendapatkan asap cair yang telah disaring selanjutnya didestilasi. Proses ini diharapkan asap cair yang dihasilkan memiliki warna yang lebih jernih dan memisahkan tar yang bersifat karsinogenik (Lestari, 2015).

Pada proses destilasi komponen yang memiliki titik didih lebih rendah akan menguap terlebih dahulu. Destilasi asap cair dilakukan pada suhu $150^{\circ} \mathrm{C}$, asap cair yang telah melewati proses destilasi disebut asap cair hasil destilasi. Pada penelitian ini asap cair tegolong grade 3, asap cair sisa destilasi tidak digunakan. Hal ini dikarenakan di asap cair sisa destilasi mengandung senyawa tar yang lebih tinggi karena tidak adanya pengaturan suhu pada saat pirolisis.

Bakteri uji yang digunakan pada penelitian ini adalah bakteri $E$. coli dan bakteri S.aureus. Asap cair yang telah dibuat dari proses diuji aktivitas antibakteri nya dengan menggunakan metode cakram. Aktivitas antibakteri ditentukan dengan mengukur diameter zona hambat pertumbuhan bakteri disekeliling kertas cakram yang sudah direndam asap cair dengan variasi volume. Uji dilakukan menggunakan asap cair tanpa destilasi dan asap cair hasil destilasi.

Asap cair yang telah diendapkan terbagi menjadi dua lapisan. Lapisan dasar yang 
Tabel 2. Hasil Analisis GC-MS Asap Cair

\begin{tabular}{cccc}
\hline \multirow{2}{*}{ No } & Nama Senyawa & \multicolumn{2}{c}{$\%$ Area } \\
& & Asap Cair \\
\cline { 3 - 4 } & & B \\
\hline 1 & Ethanal & 3,22 & - \\
2 & Acetid acid & 39,15 & 49,39 \\
3 & Acetone & 1,20 & 1,76 \\
4 & 2- Propanone, & 0,52 & 2,01 \\
& 1-hydroxy & & \\
5 & Propionic Acid & 0,75 & 2,01 \\
6 & 2-Furancarboxaldehyde & 1,62 & 0,94 \\
7 & 2-Furancarboxaldehyde- & 0,94 & 0,87 \\
\multicolumn{4}{c}{ 5 methyl } \\
8 & Benzenesulfonic acid, & 3,38 & 3,05 \\
& 4-hydroxy- \\
9 & 1,2,3- Propanetriol & 7,18 & - \\
10 & Phenol, 2- methoxy & 1,14 & - \\
11 & Phenol, 3-methyl- & 1,68 & - \\
12 & 1,2 Benzenediol & 7,03 & - \\
\hline
\end{tabular}

merupakan tar dan lapisan atas yang merupakan asap cair. Asap cair dipisahkan dari tar dengan cara disaring. Hal ini bertujuan untuk mendapatkan asap cair yang telah disaring selanjutnya didestilasi. Proses ini diharapkan asap cair yang dihasilkan memiliki warna yang lebih jernih dan memisahkan tar yang bersifat karsinogenik (Lestari, 2015).

Pada proses destilasi komponen yang memiliki titik didih lebih rendah akan menguap terlebih dahulu. Destilasi asap cair dilakukan pada suhu $150^{\circ} \mathrm{C}$, asap cair yang telah melewati proses destilasi disebut asap cair hasil destilasi. Pada penelitian ini asap cair tegolong grade 3 , asap cair sisa destilasi tidak digunakan. Hal ini dikarenakan di asap cair sisa destilasi mengandung senyawa tar yang lebih tinggi karena tidak adanya pengaturan suhu pada saat pirolisis.

Bakteri uji yang digunakan pada penelitian ini adalah bakteri $E$. coli dan bakteri S.aureus. Asap cair yang telah dibuat dari proses diuji aktivitas antibakteri nya dengan menggunakan metode cakram. Aktivitas antibakteri ditentukan dengan mengukur diameter zona hambat pertumbuhan bakteri disekeliling kertas cakram yang sudah direndam asap cair dengan variasi volume. Uji dilakukan menggunakan asap cair tanpa destilasi dan asap cair hasil destilasi.

Analisis GC-MS asap cair tanpa destilasi diperoleh 12 senyawa kimia dan asap cair hasil destilasi mengandung 7 senyawa kimia 7 senyawa kimia (Tabel 2). Komponen utama pada asap cair tanpa destilasi adalah acetid acid (39,15\%), 1,2,3Propanetriol (7,18\%), dan 1,2 Benzenediol (7,03\%) . Komponen utama asap cair hasil destilasi adalah acetid acid (49,39\%). Hasil analisis asap cair limbah kulit mangrove dengan pembakaran menunjukkan bahwa senyawa-senyawa $\mathrm{PAH}$ termasuk benzopiren tidak ditemukan pada asap cair limbah kulit batang mangrove.

\section{Kesimpulan}

Berdasarkan hasil penelitian dapat disimpulkan bahwa :

1 Asap cair tanpa destilas menunjukkan aktivitas antibakteri terhadap bakteri $E$ coli dan $S$. aureus

2 Asap cair hasil destilasi tidak menunjukkan aktivitas antibakteri

3 Analisis GC-MS mendapatkan 12 senyawa kimia dalam asap cair tanpa destilasi dan 7 senyawa kimia dalam asap cair hasil destilasi

\section{Ucapan Terima Kasih}

Penulis mengucapkan terimakasih kepada Kementerian Riset, Teknologi dan Pendidikan Tinggi Indonesia atas program PKM-P yang telah mendanai penelitian ini.

\section{Daftar Pustaka}

Bridgwater, A.V. 2004. Biomass fastpyrolysis, Thermal Science.

Dinas Kelautan dan Perikanan Provinsi Kalimantan Barat. 2014. Potensi Pulau-Pulau 
Kecil di Provinsi Kalimantan Barat dan Pengelolaannya. Kalimantan Barat

Fatimah, F. 2011. Komposisi dan Aktivitas Antibakteri Asap Cair Sabut Kelapa yang Dibuat dengan Teknik Pembakaran Non Pirolisis,. J. Agritech. 31:305-311

Harini, N, dan Wachida, M. 2014. Pengujian Efektivitas Asap Cair (Liquid Smoke) Sebagai Antibakteri Pada Berbagai Konsentrasi dan Lama Penyimpanan Pada Ikan Mujair. $J$ Gamma. 9(2):50-62.

Kondo, S., A, Wibisono, G, dan Ciptaningtyas, R. 2017. Pengaruh Pemberian Asap Cair Pada Berbagai Konsentrasi Terhadap Pertumbuhan Streptococcus Sanguis Penyebab Gingivitis. J Kedokt Diponegoro.6 (1): 106-113.

Lestari, Y., I, Idiawati, N, dan Harlia. 2015. Aktivitas Antibakteri Asap Cair Tandan Kosong Sawit Grade 2 yang Sebelumnya Diadsorpsi Zeolit Teraktivitas. $J J K K$ 4(4): 45-52.

Luditama, C. 2006. Isolasi dan Pemurnian Asap Cair Berbahan Dasar Tempurung dan Sabut Kelapa Secara Pirolisis dan Distilasi. Bogor. Institut Pertanian Bogor. Hlm 90.

Zuhud, E.M. Rahayu, W.P. Wijaya, C.H. dan Sari, P.P. 2001. Aktivitas Antimikroba Ekstrak Kedawung (Parkia roxburghii G. Don) terhadap Bakteri Pathogen. J. Teknol. Industri Pangan. 12:6-12

Zuraida, I., Hasbullah, R. Sukarno, Budijanto, S, Prabawati, S. dan Setiadjit. 2009. Aktivitas Antibakteri Asap Cair dan Daya Awetnya Terhadap Bakso Ikan. J Ilmu Perta Indo. 14(1): 41-49 